\title{
ELECTROCHEMICAL PROMOTION OF CATALYSIS (EPOC) PERSPECTIVES FOR APPLICATION TO GAS EMISSIONS TREATMENT
}

\section{A. KATSAOUNIS}

Received: 07/11/07

Accepted: $14 / 12 / 07$

\author{
Technical University of Crete \\ Department of Environmental Engineering \\ 73100, Chania, Greece
}

*to whom all correspondence should be addressed: e-mail: alex.katsaounis@enveng.tuc.gr

\begin{abstract}
Heterogeneous Catalysis and Electrocatalysis can be used very effectively on air pollution control. Air emissions coming either from mobile sources or from stationary sources, including volatile organic emissions, nitrogen oxides, hydrocarbons and carbon monoxide could be well converted to harmless non-pollutants at reasonable temperatures with cost-effective systems utilizing heterogeneous catalysis and suitable catalysts. Some of the disadvantages of conventional heterogeneous catalysts are the high production cost (since most of them are metal supported catalysts), the short life time (due to the catalyst deactivation) and the weakness to control their activity during the catalytic process. A new phenomenon of Solid State Electrochemistry called Electrochemical Promotion of Catalysis (EPOC) combined with classical heterogeneous catalysis could be applied in order to overcome some of the above problems.

In this paper we are trying to show with characteristic examples how EPOC could be useful in environmentally important reactions (oxidations, reductions, etc). The results show that EPOC reveals great perspectives in environmental issues and especially in gas emissions treatment technology. The utilization of EPOC could be really useful since we can increase the catalytic activity, alter the selectivity to the desirable products and simultaneous control the reaction rate during a given electrocatalytic process.
\end{abstract}

KEYWORDS: Emissions, catalysis, NEMCA, heterogeneous catalysis, environment, exhaust, electrocatalysis.

\section{INTRODUCTION OF EPOC}

A Greek Professor, Costas Vayenas and his group at MIT in the early eighties (Stoukides and Vayenas, 1981) were the first who reported that the catalytic activity and selectivity of conductive catalysts deposited on solid electrolytes can be altered in a very pronounced, reversible and, to some extent, predictable manner by applying electrical currents or potentials (typically up to $\pm 2 \mathrm{~V}$ ) between the catalyst and a second electronic conductor (counter electrode) also deposited on solid electrolyte. In addition to the group which first reported the EPOC, the groups of Sobyanin (Politova et al., 1990), Comninellis (Foti et al., 1997), Lambert (Harkness and Lambert, 1995), Haller (Cavalca and Haller, 1998), Anastasijevic (Anastasijevic et al., 1997), Jaksic (Neophytides et al., 1994), Stoukides (Stoukides, 1988), Yentekakis (Yentekakis et al., 1998), Smotkin (Ploense et al., 2000), Imbihl (Poppe et al., 1999), Pacchioni (Pacchioni et al., 1997), Bjerrum (Petrusina et al., 2000), Lee (Hong et al., 1996), Metcalfe (Emery et al, 1998), Janek (Janek et al., 2000) and Barbier (Lamy-Pitara et al., 2000) have also made significant contributions in this area while the importance of EPOC in electrochemistry, surface science and heterogeneous catalysis has been discussed by Bockris (Bockris and Minevski, 1994), Wieckowski (Lu and Wieckowski, 1990), Pritchard (Pritchard, 1990) and Haber (Grzybowska-Swierkosz and Haber, 1994) respectively. 


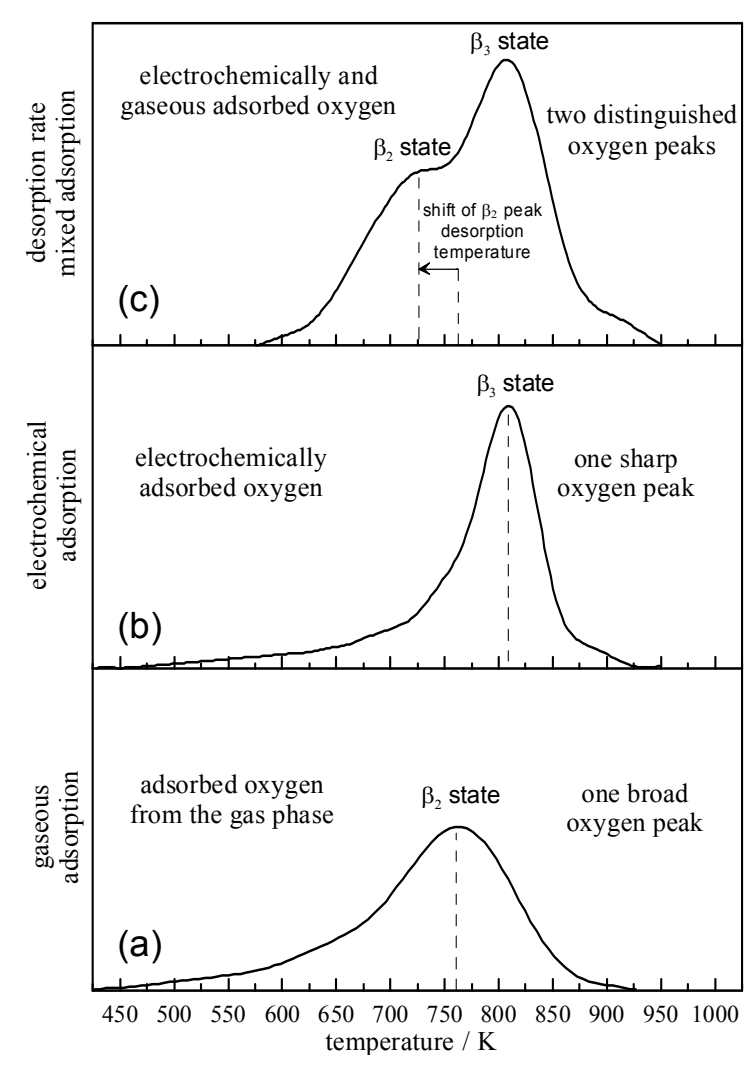

Figure 1. General behaviour of oxygen thermal desorption spectra from $\mathrm{Pt}$ thin films deposited on YSZ after oxygen adsorption at high temperatures $\left(>200^{\circ} \mathrm{C}\right)$ an heating rate $1^{\circ} \mathrm{C} \mathrm{s} \mathrm{s}^{-1}$. (a) gaseous adsorption, (b) electrochemical adsorption and (c) mixed adsorption.
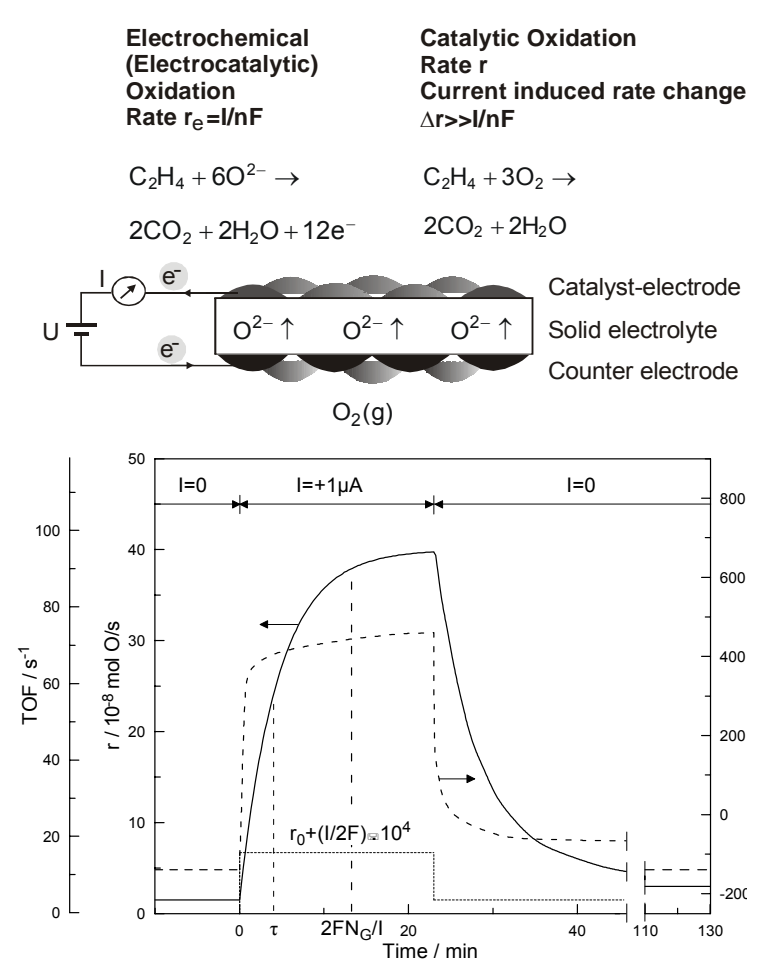

Figure 2. (a) Basic experimental setup and operating principle of EPOC with $\mathrm{O}^{2-}$ conducting supports. (b) Catalytic rate, $r$, and turnover frequency, TOF, upon step changes in applied current. $\mathrm{T}=370^{\circ} \mathrm{C}, \mathrm{p}_{\mathrm{O} 2}$ $=4.6 \mathrm{kPa}, \mathrm{p}_{\mathrm{C} 2 \mathrm{H} 4}=0.36 \mathrm{kPa}$. Also shown (dashed line) the catalyst-electrode potential, $U_{W R}$, response with respect to the reference, $\mathrm{R}$, electrode. $\mathrm{N}_{\mathrm{G}}$ is the $\mathrm{Pt} / \mathrm{gas}$ interface surface area, in mol Pt and TOF is the catalytic turnover frequency (mol $\mathrm{O}$ reacting per surface $\mathrm{Pt} \mathrm{mol} \mathrm{s}^{-1}$ ). (adapted from Bebelis and Vayenas, 1989).

Electrochemical Promotion Of Catalysis (EPOC or NEMCA effect) (Cavalca and Haller, 1998; Bockris and Minevski, 1994; Lu and Wieckowski, 1990; Pritchard, 1990; GrzybowskaSwierkosz and Haber, 1994; Vayenas et al., 1990; Lambert et al., 2000; Foti et al., 2001; Vernoux et al., 2001; Metcalf, 2001a; 2001b Leiva and Sanchez, 2003; Vayenas et al., 1996; 2001; Wieckowski et al., 2003) with ionically conducting $\left(\mathrm{Y}_{2} \mathrm{O}_{3}\right.$-stabilized- $\mathrm{ZrO}_{2}$, $\left.\mathrm{YSZ}\right)$ or mixed ionic-electronic conductors $\left(\mathrm{ZrO}_{2}, \mathrm{CeO}_{2}, \mathrm{TiO}_{2}, \mathrm{~W}^{6+}\right.$-doped-TiO $\left.\mathrm{O}_{2}\right)$ is a phenomenon of Electrocatalysis which as mentioned above affects the chemisorptive and catalytic properties of metal catalysts in a very pronounced manner. The term electrochemical promotion (Cavalca and Haller, 1998; Bockris and Minevski, 1994; Lu and Wieckowski, 1990; Pritchard, 1990; Grzybowska-Swierkosz and Haber, 1994; Vayenas et al., 1990; Lambert et al., 2000; Foti et al., 2001; Vernoux et al., 2001; Metcalf, 2001a; 2001b; Leiva and Sanchez, 2003; Vayenas et al., 1996; 2001; Wieckowski et al., 2003; Ploense et al., 1997) is used to describe the very pronounced changes observed in the catalytic properties of conductive catalysts deposited on solid electrolytes upon application of electrical currents or potentials also deposited on the solid electrolyte support. The metal catalyst is usually in the form of a porous and electronically conducting film deposited on the solid electrolyte (e.g. $\mathrm{O}^{2-}$ or mixed $\mathrm{O}^{2-}$ electronic conductor). Particularly for the case of $\mathrm{O}^{2-}$ conductor supports, the origin of EPOC 
originates from the migration (reverse spillover) of anionic $\mathrm{O}^{\delta-}$ species from the support to the metal-gas interface. These electrochemically assisted backspillover $\mathrm{O}^{\delta-}$ species together with their image charge in the metal create an overall neutral double layer at the metal-gas interface and thus affect both chemisorption and catalysis at this interface in a pronounced manner. At high oxygen coverages the backspillover $\mathrm{O}^{\delta-}$ species are distinct from, and more strongly adsorbed than, oxygen adsorbed from the gas phase (Katsaounis et al., 2004a; 2004b). They are also less reactive for catalytic oxidations than gas-supplied oxygen and thus act as sacrificial promoters (Vayenas et al., 1996; 2001; Wieckowski et al., 2003). The above mechanism supported from Figure 1 which shows the general behaviour of oxygen adsorption on polycrystalline $\mathrm{Pt}$ deposited on $\mathrm{O}^{2-}$ solid electrolytes, like YSZ. Temperature Programmed Desorption (TPD) of oxygen under Ultra High Vacuum (UHV) conditions have been used extensively to study the differential of non-stoichiometric lattice oxygen from the oxygen originating from the gas phase (Vayenas et al., 1996; 2001; Wieckowski et al., 2003). In Figure $1 \mathrm{a}$ is clearly shown one broad oxygen peak ( $\beta_{2}$ state) after catalyst (Pt/YSZ) exposure to oxygen atmosphere. In Figure $1 \mathrm{~b}$ we observe what is happening when we supply oxygen ions $\left(\mathrm{O}^{2-}\right)$ from $\mathrm{YSZ}$ using an external circuit and a constant positive current. In this case, nonstoichiometric oxygen from the support applied and adsorbed on the catalyst surface. The result is a spectrum with one sharp oxygen peak $\left(\beta_{3}\right.$ state) desorbing at higher temperatures than the oxygen of $\beta_{2}$ state. This confirms the assumption that the backspillover oxygen is more strongly adsorbed on the surface than the gaseous oxygen of $\beta_{2}$ state. If we try to carry out a mixed adsorption (from the gas phase and electrochemically, using a constant positive current) we could simulate the conditions of Electrochemical Promotion where the catalyst is exposed to an oxygen atmosphere (at least for oxidations) and at the same time $\mathrm{O}^{2-}$ applied to the surface from YSZ. Under these conditions we observe the behaviour shown in Figure 1c. Two distinguished oxygen peaks, one broad coming from the gas phase $\left(\beta_{2}\right.$ state) and another one ( $\beta_{3}$ state) sparper and more strongly bonded with the surface. What is very interesting is that the existence of $\beta_{3}$ state which represents the backspillover oxygen acts as a sacrificial promoter for gaseous oxygen since the last moves to more weakly (and as a result more reactive) bonded states on the surface (lower desorption temperatures). More discussion about the above mechanism of electrochemical promotion exists elsewhere (Vayenas et al., 1996; 2001; Wieckowski et al., 2003; Ploense et al., 1997; Katsaounis et al., 2004a; 2004b; Vayenas et al., 1995; Vayenas and Neophytides, 1996).

Figures 2 and 3 describe more schematically the basic phenomenon of EPOC when using $\mathrm{O}^{2-}$ and $\mathrm{H}^{+}$conducting supports respectively. In the former case (Figure 2) the (usually porous) metal (Pt) catalyst-electrode, typically $40 \mathrm{~nm}$ to $4 \mu \mathrm{m}$ thick, is deposited on an $8 \mathrm{~mol} \% \mathrm{Y}_{2} \mathrm{O}_{3^{-}}$ stabilized-ZrO 2 (YSZ) solid electrolyte. In the latter case (Figure 3 ) the nanodispersed $\mathrm{Pd}$ catalyst is deposited on porous conductive graphitic $\mathrm{C}$ which is supported on Nafion, a $\mathrm{H}^{+}$ conductor. In both cases under open-circuit operation ( $I=0$, no electrochemical rate) there is a catalytic rate, $r_{o}$, of ethylene consumption for oxidation to $\mathrm{CO}_{2}$ (Figure 2) or of 1-butene consumption due to reduction to butane and isomerization to cis-2-butene and trans-2-butene (Figure 3). Application of an electrical current, I, or potential, $U_{W R}$, between the catalyst and a counter electrode and thus change of the catalyst potential, $U_{W R}$, with respect to a reference electrode, causes very pronounced and strongly non-Faradaic (i.e. $\Delta \mathrm{r}>>\mathrm{I} / 2 \mathrm{~F}$ in Figure 2, $\Delta r>>|-| / F \mid$ in Figure 3) alterations to the catalytic rate (Figures 2 and 3 ) and to the product selectivity (Figure 3). Two parameters are commonly used to describe the magnitude of EPOC:

1. The apparent Faradaic efficiency, $\Lambda$ :

$\Lambda=\frac{\Delta \mathrm{r}_{\text {catalytic }}}{(\mathrm{I} / 2 \mathrm{~F})}$

where $\Delta r_{\text {catalytic }}$ is the current-or potential-induced change in catalytic rate, $\mathrm{I}$ is the applied current and $\mathrm{F}$ is the Faraday's constant. 
2. The rate enhancement, $\rho$ :

$$
\rho=\frac{r}{r_{0}}
$$

where $r$ is the electropromoted catalytic rate and $r_{0}$ is the unpromoted (open-circuit) catalytic rate.

A reaction exhibits electrochemical promotion when $|\Lambda|>1$, while electrocatalysis is limited to $|\Lambda|=1$. A reaction is termed electrophobic when $\Lambda>1$ and electrophilic when $\Lambda<-1$. In the former case the rate increases with catalyst potential, $U_{W R}$, while in the latter case the rate decreases with catalyst potential. $\Lambda$ values up to $3 \times 10^{5}$ and $\rho$ values up to 150 (Vayenas et al., 2001) have been found for several systems. More recently $\rho$ values between 300 (Koutsodontis et al., 2006a; 2006b) and 1350 (Bebelis and Kotsionopoulos, 2006) have been measured for $\mathrm{C}_{2} \mathrm{H}_{4}$ oxidation on $\mathrm{Pt}$. In the experiment of Figure 2, $\Lambda=$ 74,000 and $\rho=26$, i.e. the rate of $\mathrm{C}_{2} \mathrm{H}_{4}$ oxidation increases by a factor of 25 and the increase in the rate of $\mathrm{O}$ consumption is 74,000 times larger than the rate, $1 / 2 \mathrm{~F}$, of $\mathrm{O}^{2-}$ supply to the catalyst. In the experiment of Figure 3 the maximum $\rho$ values for the production of cis-2-butene, trans-2-butene and butene are of the order of 50 and the corresponding maximum $\Lambda$ values are of the order of 40 for cis-2-butene formation, 10 for trans-2-butene formation and less than one for butane formation. Thus, each proton supplied to the $\mathrm{Pd}$ catalyst can cause the isomerization of up to 40 1-butene molecules to cis-2butene and up to 101 -butene molecules to trans-2-butene while the hydrogenation of 1 butene to butane is electrocatalytic, i.e. Faradaic.

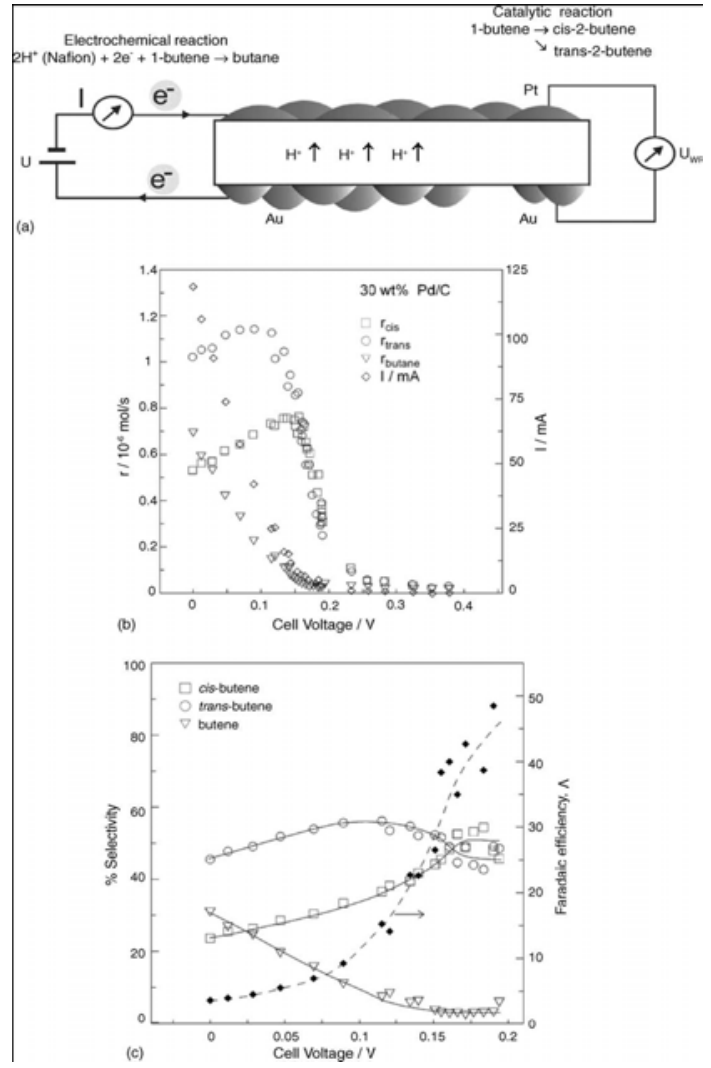

Figure 3. (a) Basic experimental setup and operating principle of EPOC using a $\mathrm{H}^{+}$ conductor during 1-butene isomerization to cis-2butene and trans-2-butene on $\mathrm{C}$ supported $\mathrm{Pd}$. (b) Electrochemical promotion of the isomerization reaction. Steady-state effect of cell potential on the cell current, I, and on the rates of formation of cis-2-butene, trans-2-butene and butane produced from 1-butene supplied over a dispersed $\mathrm{Pd} / \mathrm{C}$ catalyst-electrode deposited on Nafion, a $\mathrm{H}^{+}$conductor. (c) Corresponding effect of cell potential on the selectivities to cis-2butene, trans-2-butene and butane and on the apparent Faradaic efficiency, $\Lambda$ (adapted from Ploense et al., 2000).

\section{APPLICATIONS OF EPOC ON ENVIRONMENTALLY IMPORTANT SYSTEMS}

Up to 2001 (Vayenas et al., 2001), more than 70 different catalytic reactions (oxidations, hydrogenations, dehydrogenations, isomerizations, decompositions) had been electrochemically promoted on $\mathrm{Pt}, \mathrm{Pd}, \mathrm{Rh}, \mathrm{Ag}, \mathrm{Au}, \mathrm{Ni}, \mathrm{IrO}_{2}, \mathrm{RuO}_{2}$ catalysts deposited on $\mathrm{O}^{2-}$ (YSZ), $\mathrm{Na}^{+}\left(\beta^{\prime \prime}-\mathrm{Al}_{2} \mathrm{O}_{3}\right), \mathrm{H}^{+}\left(\mathrm{CaZr}_{0.9} \mathrm{In}_{0.1} \mathrm{O}_{3-a}\right.$, Nafion (Ploense et al., 1997; Tsiplakides et al., 1997)), $\mathrm{F}^{-}\left(\mathrm{CaF}_{2}\right)$, aqueous (Neophytides et al., 1994; Lamy-Pitara et al., 2000), molten salt (Petrushina et al., 2000) and mixed ionic-electronic $\left(\mathrm{TiO}_{2}\right.$ (Pliangos et al., 1996), $\mathrm{CeO}_{2}$ (Balomenou et al., 1998)) conductors. EPOC seems to be not limited to any particular class of conductive catalyst, catalytic reaction or ionic support. It can be used in order to affect the rate and selectivity of heterogeneous catalytic reactions in a reversible and very pronounced manner. This non-Faradaic activation of heterogeneous catalytic reactions is a novel and promising application of electrochemistry with several technological possibilities, particularly in industrial product selectivity modification and in exhaust gas treatment (Vayenas et al., 2001). The second case is very important from environmental point of view. In the next few paragraphs we will examine applications of EPOC on particular catalytic systems both with environmental and industrial interest. 
$\mathrm{C}_{2} \mathrm{H}_{4}$ oxidation: One of the most well studied reaction using EPOC is the complete oxidation of ethylene to $\mathrm{CO}_{2}$ using various metals ( $\mathrm{Pt}, \mathrm{Rh}, \mathrm{Pd})$ and metal oxides $\left(\mathrm{IrO}_{2}\right.$, $\left.\mathrm{RuO}_{2}, \mathrm{IrO}_{2}-\mathrm{TiO}_{2}\right)$ deposited either on anionic or cationic conductors (Vayenas et al., 2001). We can observe characteristically in Figure 2, using $\mathrm{Pt} / \mathrm{YSZ}$, that a very small positive applied current $(1 \mu \mathrm{A})$ causes a 26 -fold increase in catalytic rate $(\rho=26)$ while the rate increase is 74000 times larger than the rate $\mathrm{I} / 2 \mathrm{~F}$ of $\mathrm{O}^{2-}$ supply to the catalyst $(\Lambda=74000)$ (Bebelis and Vayenas, 1989). It's worth noting that this increase is fully reversible since after current interruption the catalytic rate decreases to its initial value. Recently (Koutsodontis et al., 2006a; 2006b) it was found that for the same reaction $\left(\mathrm{C}_{2} \mathrm{H}_{4}\right.$ oxidation), using very thin films of $\mathrm{Pt}$ deposited on YSZ, using the metal sputtering technique, it is possible to affect dramatically the catalytic rate of the reaction both under anodic and cathodic polarization (Figure 4). Rate enhancement values up to 300 were obtained while the $\Lambda$ values were up to 500 .

Other light hydrocarbon oxidations: In addition to $\mathrm{C}_{2} \mathrm{H}_{4}$, other hydrocarbons like $\mathrm{CH}_{4}, \mathrm{C}_{2} \mathrm{H}_{6}$, $\mathrm{C}_{3} \mathrm{H}_{6}, \mathrm{C}_{3} \mathrm{H}_{6}$ or even alcohols like $\mathrm{CH}_{3} \mathrm{OH}$ (Vayenas et al., 2001) exhibit very good behaviour under electropromoted conditions during complete oxidation to $\mathrm{CO}_{2}$. It has been found that $\mathrm{C}_{2} \mathrm{H}_{6}$ oxidation on Pt/YSZ (Kaloyannis and Vayenas, 1999) under oxidizing conditions exhibits electrophobic behaviour for positive applied currents and electrophilic behaviour for negative polarizations, i.e. it exhibits inverted volcano behaviour. In the case of positive potentials $\rho$ values up to 20 and $\Lambda$ values up to 300 were observed, while in the case of negative potentials these values were 7 and -100 respectively. Using the same type of catalyst (Pt/YSZ) $\mathrm{C}_{3} \mathrm{H}_{6}$ oxidation was studied at temperatures between 300 and $500^{\circ} \mathrm{C}$ (Kaloyannis and Vayenas, 1999), resulting under oxidizing conditions and anodic polarization $\rho$ values up to 6 and $\Lambda$ values up to -3000 (case of purely electrophilic behaviour). Methane oxidation is another reaction exhibiting electrophobic behaviour for positive overpotentials both for Pt and $\mathrm{Pd}$ catalysts. In the case of Pt/YSZ (Tsiakaras and Vayenas, 1993; Eng and Stoukides, 1991) strong rate enhancement is also obtained with negative change of work function, $\Delta \Phi$, leading to inverted volcano type behaviour. The effect of $U_{W R}$ on catalytic rate is more pronounced when high $\mathrm{CH}_{4}$ to $\mathrm{O}_{2}$ ratios are used. For a $40: 1 \mathrm{CH}_{4}$ to $\mathrm{O}_{2}$ feed ratio at $700^{\circ} \mathrm{C}$, a seventy-fold increase in catalytic rate is obtained for $\Delta \Phi=1 \mathrm{eV}$. This is due to the weakening of the $\mathrm{Pt}=\mathrm{O}$ bond with increasing work function. Rate enhancement factors $\Lambda$ are low, typically less than five, due to the high operating temperatures and concomitantly high $\mathrm{I}_{\mathrm{o}}$ (exchange current of the catalyst-solid electrolyte interface) values. The $\mathrm{CH}_{4}$ oxidation on Pd (Frantzis et al., 2000) exhibits a very pronounced NEMCA behaviour at much lower temperatures $\left(380-440^{\circ} \mathrm{C}\right)$ compared with those on Pt catalysts $\left(650-750^{\circ} \mathrm{C}\right)$. For positive overpotentials the $\rho$ values are as high as 89 , with $\Lambda$ values up to 105 . Negative overpotentials also enhance the rate with $\rho$ values up to 8.

CO oxidation: CO oxidation is another environmentally important reaction where a NonFaradaic rate enhancement was observed using various noble metals on YSZ. Typically $\Lambda$ values using $\mathrm{Pt} / \mathrm{YSZ}$ and oxidizing conditions at $550^{\circ} \mathrm{C}$ (Yentekakis and Vayenas, 1988) were of the order of $10^{2}-10^{3}$ while $\rho$ values were typically up to five. Using Ag/YSZ (Karavasilis et al., 1991) the reaction of CO oxidation exhibits electrophobic $(\Lambda>0)$ behaviour for high catalyst potentials and electrophilic behaviour for low catalyst work function values. Typical $\Lambda$ values under oxidizing conditions at $415{ }^{\circ} \mathrm{C}$ were of the order of 20 in the electrophobic region and of 
the order of -800 in the electrophilic one. The oxidation of $\mathrm{CO}$ on $\mathrm{Ag}-25 \mathrm{~mol} \% \mathrm{Pd}$ alloys deposited on YSZ by Sobyanin and coworkers (Politova et al., 1997) was the first electrochemical promotion study utilizing an alloy catalyst. The rate was significantly enhanced with negative polarization giving $\rho$ values up to 20 .


Figure 5. Effect of the catalyst potential on the $\mathrm{CO}_{2}, \mathrm{~N}_{2}, \mathrm{~N}_{2} \mathrm{O}$ formation rates and the selectivity of $\mathrm{NO}$ reduction to $\mathrm{N}_{2}$. Conditions: $\mathrm{T}=373^{\circ} \mathrm{C}$, inlet composition: $\mathrm{p}_{\mathrm{NO}}^{\circ}=1.34 \mathrm{kPa}$, $\mathrm{p}_{\mathrm{CO}}^{\mathrm{o}}=0.55 \mathrm{kPa}$. (adapted from Marwood and Vayenas (1997))

Figure 6. Transient effect of a constant applied current on the catalytic rates of $\mathrm{CO}_{2}$ production, on NO conversion $\left(\mathrm{X}_{\mathrm{No}}\right)$ and on catalyst potential during No reduction by $\mathrm{C}_{3} \mathrm{H}_{6}$ on $\mathrm{Rh} / \mathrm{SZ}$ in presence of gaseous $\mathrm{O}_{2}$ (adapted from Pliangos et al., 2000b)

From the above examples we can conclude that electrochemical promotion is a very useful tool when we have to deal with a hydrocarbon oxidation. The effectiveness of the above phenomenon have been confirmed either for partial or complete oxidation reactions. What is happening however if we have to face other gas emissions like nitrogen oxides $\left(\mathrm{NO}_{\mathrm{x}}\right)$ or even sulfur dioxide $\mathrm{SO}_{2}$ ? In this case the catalytic process concerns a reduction of a particular oxide, i.e. a much more difficult catalytic reaction. Let us see if EPOC can be useful in this case.

NO Reduction: Reactions involving the catalytic reduction of nitrogen oxides are of major environmental importance for the removal of toxic emissions from both stationary and automotive sources. EPOC can affect dramatically the performance of $\mathrm{Rh}, \mathrm{Pd}$ and $\mathrm{Pt}$ (Marwood et al., 1996; Marwood and Vayenas, 1997; Haller and Kim, 1997; Pliangos et al., $2000 \mathrm{a} ; 2000 \mathrm{~b}$; 2000c) catalysts (commonly used as exhaust catalysts) interfaced with YSZ, an $\mathrm{O}^{2-}$ conductor. The main feature is strong electrophilic behaviour, i.e. enhanced rate and $\mathrm{N}_{2}$ selectivity behaviour with decreasing catalyst potential, $U_{W R}$ and work function, $\Phi$ due to $\mathrm{NO}$ dissociation enhancement. Both $\mathrm{NO}$ and $\mathrm{N}_{2} \mathrm{O}$ reduction on $\mathrm{Pd} / \mathrm{YSZ}$ (Marwood et al., 1996; Marwood and Vayenas, 1997) exhibit electrophilic NEMCA behaviour at the temperature range of $350-500^{\circ} \mathrm{C}$. The catalytic activity of $\mathrm{Pd}$ for the reduction of $\mathrm{NO}$ or $\mathrm{N}_{2} \mathrm{O}$ by $\mathrm{CO}$ (Marwood et al., 1996; Marwood and Vayenas, 1997) was enhanced up to $300 \%$ and $200 \%$ respectively, while the rate increase of NO reduction was typically more than 700 times larger than the rate of $\mathrm{O}^{2-}$ removal from the catalyst via negative current application. This is shown in Figure 5. Positive potentials cause no promotional effect on the catalyst performance. On the contrary, as the catalyst potential decreases, all catalytic rates start to increase and the system exhibits electrophilic NEMCA behaviour. These changes in catalytic activity are accompanied by significant changes in nitrogen selectivity. The enhancement of the nitrogen selectivity with negative currents or potentials is due to the enhanced dissociative adsorption 
of NO. The formation of $\mathrm{N}_{2} \mathrm{O}$ results from the reaction between atomic nitrogen, $\mathrm{N}(\mathrm{a})$ (originating from a dissociatively adsorbed NO) and a molecularly adsorbed NO. Thus, decreasing the coverage of $\mathrm{NO}$ and increasing the coverage of $\mathrm{N}$ favours the formation of $\mathrm{N}_{2}$ vs that of $\mathrm{N}_{2} \mathrm{O}$.

The $\mathrm{C}_{2} \mathrm{H}_{4} / \mathrm{NO}$ reaction is a commonly studied model catalytic system for the reduction of NO by a light hydrocarbon (Marwood et al., 1996). The kinetic and NEMCA investigation of this system was carried out on polycrystalline Pt interfaced with YSZ The reaction was studied at the temperature range of $380-500^{\circ} \mathrm{C}$ for gaseous compositions $\mathrm{p}_{\mathrm{NO}}=0-2 \mathrm{kPa}$ and $\mathrm{p}_{\mathrm{C} 2 \mathrm{H} 4}=0-4 \mathrm{kPa}$. The system exhibits remarkable electrophilic promotional behaviour with $\rho$ values up to 20 . Application of negative currents between the Pt catalyst-working electrode and the Au counter electrode causes a sharp increase in all reaction rates. In the new steady state of the catalyst (achieved within $1 \mathrm{hr}$ of current application) the catalytic rate increase of $\mathrm{CO}_{2}$ and $\mathrm{N}_{2}$ production is about $700 \%$, while smaller increase (250-400\%) is observed in the rates of CO and $\mathrm{N}_{2} \mathrm{O}$ production.

The presence of oxygen in the feed composition poses a challenging problem in NO reduction processes. Particularly, in high excess of oxygen, which is the case in lean burn or diesel engines, the high $\mathrm{O}$ coverage dominates the catalyst surface and blocks active sites needed for NO adsorption and dissociation. Due to the great environmental importance of such processes, the reduction of $\mathrm{NO}_{x}$ under lean burn conditions has attracted a large number of investigations during the last years. The NEMCA behavior of $\mathrm{NO}$ reduction by $\mathrm{C}_{3} \mathrm{H}_{6}$ on $\mathrm{Rh} / \mathrm{YSZ}$ (Pliangos et al., 2000a; 2000b; 2000c) is very pronounced and significantly different from $\mathrm{NO}$ reduction in absence of gaseous $\mathrm{O}_{2}$. Thus, while in absence of $\mathrm{O}_{2}$ the main goal of electrochemical promotion is to enhance NO dissociation, and this is achieved by lowering the work function via negative potential application, in the presence of oxygen it becomes at least equally important to weaken the $\mathrm{Rh}=\mathrm{O}$ chemisorptive bond thus enhance the relative $\mathrm{NO}$ vs $\mathrm{O}$ coverage. The rates of $\mathrm{N}_{2}$ and $\mathrm{CO}_{2}$ formation are enhanced dramatically both with positive and with negative $\Delta U_{W R}$ and $\Delta \Phi$. As we can see in Figure 6 positive potential or current application leads to rate enhancement, $\rho$, values up to 125 for the rate of $\mathrm{CO}_{2}$ formation and up to 50 for the rate of $\mathrm{N}_{2}$ formation.

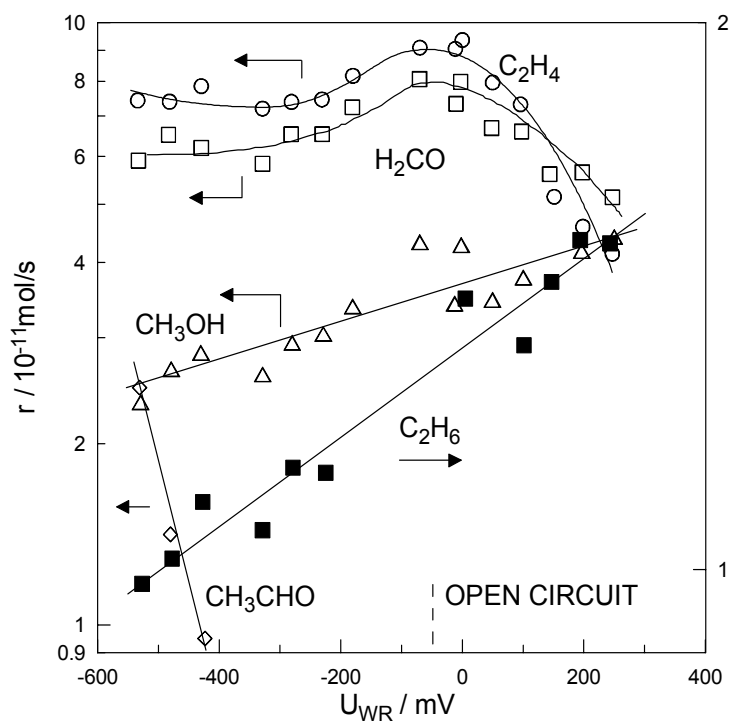

Figure 7. Effect of catalyst potential on the rates of formation of $\mathrm{C}_{2} \mathrm{H}_{6}, \mathrm{C}_{2} \mathrm{H}_{4}, \mathrm{H}_{2} \mathrm{CO}, \mathrm{CH}_{3} \mathrm{OH}$ and $\mathrm{CH}_{3} \mathrm{CHO}$ during $\mathrm{CO}$ hydrogenation on $\mathrm{Pd} / \mathrm{YSZ}$, $\mathrm{T}=350^{\circ} \mathrm{C}, \mathrm{p}_{\mathrm{H}_{2}} / \mathrm{p}_{\mathrm{CO}}=1.8$, flowrate $85 \mathrm{~cm}^{3}$ STP $\mathrm{min}^{-1}$. (adapted from Karasali, 1994)

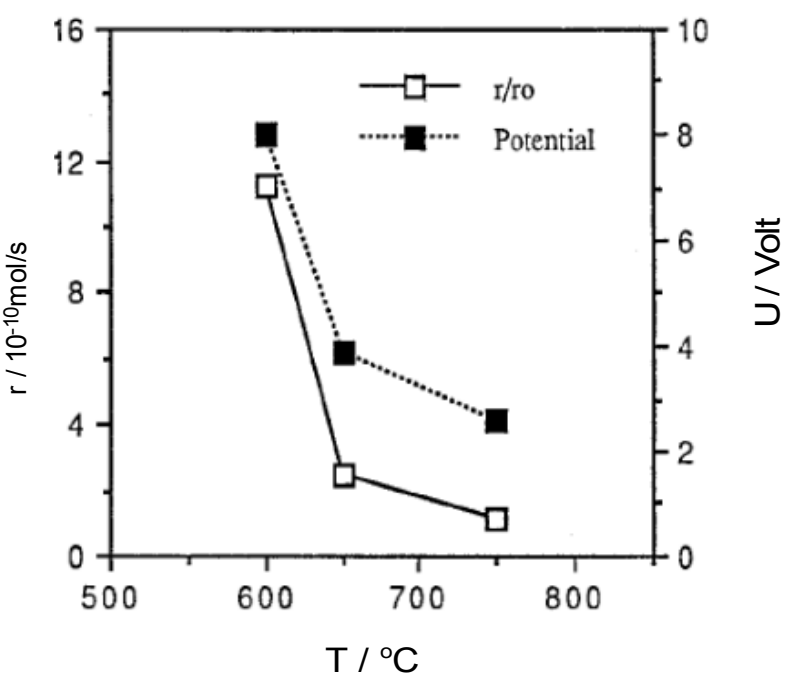

Figure 8. Temperature dependence of $\rho$ and $U$ for the electrocatalytic decomposition of hydrogen sulfide under constant current 10mA (based on Alqahtany et al., 1992)

$\mathrm{CO}_{2}$ and $\mathrm{CO}$ hydrogenation: Another aspect of heterogeneous catalysis with environmental interest is the hydrogenation reactions. One of the most important subjects nowadays is the degradation of $\mathrm{CO}_{2}$. The hydrogenation of $\mathrm{CO}$ and $\mathrm{CO}_{2}$ on transition metal surfaces is a 
promising area for using EPOC to affect rates and selectivities. In an older study of $\mathrm{CO}_{2}$ hydrogenation on $\mathrm{Rh} / \mathrm{YSZ}$ (Karasali, 1994) where the products were mainly $\mathrm{CH}_{4}$ and $\mathrm{CO}$, under atmospheric pressure at temperatures between 300 and $500^{\circ} \mathrm{C}$, it was found that $\mathrm{CH}_{4}$ formation is electrophobic while $\mathrm{CO}$ formation is electrophilic. The observed increase in $\mathrm{CH}_{4}$ formation and simultaneous decrease in $\mathrm{CO}$ formation with increasing catalyst potential and work function (i.e. with increasing supply of $\mathrm{O}^{2-}$ to the catalyst) is remarkable and can be attributed to the preferential formation on the $\mathrm{Rh}$ surface of electron donor hydrogenated carbonylic species leading to formation of $\mathrm{CH}_{4}$ and to the decreasing coverage of more electron acceptor carbonylic species resulting in CO formation. Using Pd/YSZ (Karasali, 1994) for the hydrogenation of CO at a total pressure of 12.5 bar and temperatures of $330-370^{\circ} \mathrm{C}$, a variety of products was obtained, including hydrocarbons $\left(\mathrm{CH}_{4}, \mathrm{C}_{2} \mathrm{H}_{4}, \mathrm{C}_{2} \mathrm{H}_{6}\right)$, alcohols $\left(\mathrm{CH}_{3} \mathrm{OH}\right)$ and aldehydes $(\mathrm{HCHO}$, $\mathrm{CH}_{3} \mathrm{CHO}$ ). It was found that both the catalytic rates and the selectivity to the various products can be altered significantly (rate changes up to $250 \%$ were observed) and reversibly under NEMCA conditions. Depending on the product, electrophobic or electrophilic behaviour is observed as shown in Figure 7.

$\mathrm{H}_{2} \mathrm{~S}$ dehydrogenation: EPOC can even affect the $\mathrm{H}_{2} \mathrm{~S}$ dehydrogenation, one of the most difficult reaction in heterogeneous catalysis. This reaction was investigated by Stoukides and coworkers (Alqahtany et al., 1992) at temperatures between 600 and $750^{\circ} \mathrm{C}$. The reaction was found to be electrophobic with $\rho$ values up to 11 (Figure 8). The rate of $\mathrm{H}_{2} \mathrm{~S}$ decomposition was found to increase exponentially with $U_{W R}$ and to increase slowly during galvanostatic transients (i.e. constant current applications).

\section{SUMMARY}

From the above examples is clear enough that EPOC can affect a variety of reaction types, most of them with great environmental interest. The successful utilization of EPOC under tough conditions could help to deal effectively with gas exhausts like hydrocarbons or oxides $\left(\mathrm{NO}_{\mathrm{x}}\right.$, $\mathrm{SO}_{2}$ e.t.c). Also the above effect could lead to the development of catalysts with lower metal loading which is very important from economic point of view. The possibility of the reaction rate control via EPOC is also something very useful in the procedure of gas emission treatment. The commercialization of EPOC was enhanced after the development of the Monolithic Electrochemical Promoted Reactor (MEPR) which can be considered as a hybrid between a classical monolithic honeycomb reactor (of which it has all the geometric dimensions) and of a flat - or ribbed - plate solid oxide fuel cell. This compact and efficient reactor design appears to be significantly promising for practical applications. Using the above reactor (MEPR) basic laboratory problems like expensive catalyst films or very low metal dispersions can be overcome with great success (Balomenou et al., 2004; 2006). The effectiveness of the reactor has been already proved since MEPR used successfully both for oxidations and reductions under really hard feeding conditions (for example: gas stream coming from a diesel engine) (Balomenou et al., 2004; 2006).

\section{ACKNOWLEDGEMENTS}

The author would like to thank Professor Costas Vayenas for his permission to use a part of the results of his group and also for his friendship and trust during the last 10 year.

\section{REFERENCES}

Alqahtany H., Chiang P. H., Eng P., Stoukides M. and Robbat A.R. (1992) Electrocatalytic Decomposition of Hydrogen Sulfide, Catal. Lett., 13, 289-295.

Anastasijevic N.A., Hillrichs E., Lohrberg K. and Ungar G. (1997), US Patent 5,637,206.

Balomenou S., Tsiplakides D., Katsaounis A., Brosda S., Hammad A., Foti G., Comninellis Ch., Tieman-Handler S., Cramer B. and Vayenas C.G. (2006) Monolithic electrochemically promoted reactors: A step for the practical utilization of electrochemical promotion, Solid State Ionics, 177, 2201-2204.

Balomenou S., Tsiplakides D., Katsaounis A., Tieman-Handler S., Cramer B., Foti G., Comninellis Ch. and Vayenas C.G. (2004) Novel monolithic electrochemically promoted catalytic reactor for environmentally important reactions, Appied Catalysis B: Environmental, 52, 181-196. 
Bebelis S. and Kotsionopoulos N. (2006) Non-faradaic electrochemical modification of the catalytic activity for propane combustion of Pt/YSZ and Rh/YSZ catalyst-electrodes, Solid State Ionics, 177, 2205-2209.

Bebelis S. and Vayenas C.G. (1989) Non-Faradaic Electrochemical Modification of Catalytic Activity: 1 . The case of Ethylene Oxidation on Pt, J. Catal., 118, 125-146.

Bockris J.O.M. and Minevski Z.S. (1994) Electrocatalysis: past, present and future, Electrochim. Acta, 39, 1471-1479.

Cavalca C.A. and Haller G.L. (1998) Solid electrolytes as active catalyst supports: Electrochemical modification of benzene hydrogenation activity on $\mathrm{Pt} / \beta^{\prime \prime}(\mathrm{Na}) \mathrm{Al}_{2} \mathrm{O}_{3}$, J. Catal., 177, 389-395.

Emery D.A., Middleton P.H., and Metcalfe I.S. (1998) The effect of electrochemical current pumping on the work function of solid electrolyte supported catalysts, Surf. Sci., 405, 308-315.

Eng D. and Stoukides M. (1991) Catalytic and electrochemical oxidation of methane on platinum, J. Catal., 130, 306-309.

Foti G., Gandini D. and Comninellis C. (1997) Anodic oxidation of organics on thermally prepared oxide electrodes, Current Topics in Electrochemistry, 5, 71-91.

Foti G., Wodiunig S. and Comninellis C. (2001) Electrochemical promotion of catalysts for gas phase reactions, Current topics in Electrochemistry, 7, 1-22.

Frantzis A.D., Bebelis S. and Vayenas C.G. (2000) Electrochemical promotion (NEMCA) of $\mathrm{CH}_{4}$ and $\mathrm{C}_{2} \mathrm{H}_{4}$ oxidation on $\mathrm{Pd} / \mathrm{YSZ}$ and investigation of the origin of NEMCA via AC impedance spectroscopy, Solid State Ionics, 136-137, 863-872.

Grzybowska-Swierkosz B. and Haber J. (1994) Catalysis, Annu. Rep. Prog. Chem., Sect. C: Phys. Chem., 91, 395-439.

Haller G.L. and Kim S. (1997), ACS Petroleum Division Preprints, Symposium in Catalytic Combustion in 213th National ACS Meeting (San Francisco, CA), 155-158.

Harkness I. and Lambert R.M. (1995), Electrochemical Promotion of the No + Ethylene Reaction over Platinum, J. Catal., 152, 211-214.

Hong J.K., Oh I.-H., Hong S.-A. and Lee W.Y. (1996), Electrochemical Oxidation of Methanol over a Silver Electrode Deposited on Yttria-Stabilized Zirconia Electrolyte, J. Catal., 163, 95-105.

Janek J., Rohnke M., Luerssen B. and Imbihl R. (2000) Promotion of catalytic reactions by electrochemical polarization, Phys. Chem. Chem. Phys., 2,1935-1941.

Kaloyannis A. and Vayenas C.G. (1999) Non-Faradaic Electrochemical Modification of Catalytic Activity: 12. Propylene Oxidation on Pt, J. Catal., 182, 37-47.

Karasali H. (1994), Electrochemical Promotion of $\mathrm{CO}$ oxidation and $\mathrm{CO}, \mathrm{CO}_{2}$ hydrogenation on transition metals, phD Thesis, Department of Chemical Engineering, University of Patras, Patras.

Karavasilis C., Bebelis S. and Vayenas C.G. (1991) NEMCA: The Oxidation of CO on Ag, Materials Science Forum, 76, 175-178.

Katsaounis A., Brosda S. and Vayenas C.G. (2007) Electrocatalysis, in Encyclopedia of Electrochemistry by Bard A.J. and Stratmann M. (Eds.), Wiley-VCH Verlag GmbH \& Co.

Katsaounis A., Nikopoulou Z., Verykios X.E. and Vayenas C.G. (2004a) Comparative isotopeaided investigation of electrochemical promotion and metal-support interactions $1 .{ }^{18} \mathrm{O}_{2}$ TPD of electropromoted Pt films deposited on YSZ and of dispersed Pt/YSZ catalysts, J. Catal., 222, 192-206.

Katsaounis A., Nikopoulou Z., Verykios X.E. and Vayenas C.G. (2004b) Comparative isotopeaided investigation of electrochemical promotion and metal-support interactions: 2.CO oxidation by ${ }^{18} \mathrm{O}_{2}$ on electropromoted $\mathrm{Pt}$ films deposited on $\mathrm{YSZ}$ and on nanodispersed $\mathrm{Pt} / \mathrm{YSZ}$ catalysts, J. Catal., 226, 197-209.

Koutsodontis C., Katsaounis A., Figueroa J.C., Cavalca C., Pereira C. and Vayenas C.G. (2006a) The effect of catalyst film thickness on the electrochemical promotion of ethylene oxidation on $\mathrm{Pt}$, Topics in Catalysis, 39, 97-100.

Koutsodontis C., Katsaounis A., Figueroa J.C., Cavalca C., Pereira C.J. and Vayenas C.G. (2006b) The effect of catalyst film thickness on the magnitude of the electrochemical promotion of catalytic reactions, Topics in Catalysis, 38, 157-167.

Lambert R.M., Williams F., Palermo A. and Tikhov M.S. (2000) Modelling alkali promotion in heterogeneous catalysis: in situ electrochemical control of catalytic reactions, Topics in Catalysis, 13, 91-95. 
Lamy-Pitara E., Mouahid S.E. and Barbier J. (2000) Effect of anions on catalytic and electrocatalytic hydrogenations and on the electrocatalytic oxidation and evolution of hydrogen on platinum, Electrochim. Acta, 45, 4299-4308.

Leiva E.P.M. and Sanchez C.G. (2003) NEMCA effect: why are the work function changes of the gas exposed catalyst-electrode surface one-to-one related to the changes in the catalyst working electrode potential?, Journal of Solid State Electrochemistry, 7, 588-592.

Lu G.-Q. and Wieckowski A. (2000) Heterogeneous electrocatalysis: a core field of interfacial science, Current opinion in Colloid and Interface Science, 5, 95-100.

Marwood M. and Vayenas C.G. (1997) Electrochemical Promotion of the Catalytic Reduction of NO by CO on Palladium, J. Catal., 170, 275-285.

Marwood M., Kaloyannis A. and Vayenas C.G. (1996) Electrochemical promotion of the NO reduction by $\mathrm{C}_{2} \mathrm{H}_{4}$ on $\mathrm{Pt} / \mathrm{YSZ}$ and by $\mathrm{CO}$ on $\mathrm{Pd} / \mathrm{YSZ}$, lonics, 2, 302-311.

Metcalfe I. (2001) Electrochemical Promotion of Catalysis: I: Thermodynamic Considerations, J. Catal., 199, 247-258.

Metcalfe I. (2001) Electrochemical Promotion of Catalysis: II: The Role of a Stable Spillover Species and Prediction of Reaction Rate Modification, J. Catal., 199, 259-272.

Neophytides S., Tsiplakides D., Stonehart P., Jaksic M. and Vayenas C. G. (1994), Electrochemical enhancement of a catalytic reaction in aqueous solution, Nature, 370, 45-47.

Pacchioni G., Lomas J.R. and Illas F. (1997) Electric field effects in heterogeneous catalysis, Molecular Catalysis A: Chemical, 119, 263 -273.

Petrolekas P., Balomenou S. and Vayenas C.G. (1998) Electrochemical Promotion of Ethylene Oxidation on Pt Catalyst Films Deposited on $\mathrm{CeO}_{2}$, J. Electrochem. Soc., 145, 1202-1206.

Petrushina I.M., Bandur V.A., Cappeln F. and Bjerrum N.J. (2000) Electrochemical Promotion of Sulfur Dioxide Catalytic Oxidation, J. Electrochem. Soc., 147, 3010-3013.

Pliangos C., Raptis C., Badas T. and Vayenas C.G. (2000a) Electrochemical promotion of NO reduction by $\mathrm{C}_{3} \mathrm{H}_{6}$ and $\mathrm{CO}$ on Rh/YSZ catalyst - Electrodes, lonics, 6,119-126.

Pliangos C., Raptis C., Badas T. and Vayenas C.G. (2000b) Electrochemical promotion of NO reduction by $\mathrm{C}_{3} \mathrm{H}_{6}$ on $\mathrm{Rh} / \mathrm{YSZ}$ catalyst-electrodes, Solid State Ionics, 136-137, 767-773.

Pliangos C., Raptis C., Badas T., Tsiplakides D. and Vayenas C.G. (2000c) Electrochemical promotion of a classically promoted Rh catalyst for the reduction of NO, Electrochim. Acta, 46, 331-339.

Pliangos C., Yentekakis I.V., Ladas S. and Vayenas C.G. (1996) Non-Faradaic Electrochemical Modification of Catalytic Activity: 9. Ethylene Oxidation on Pt Deposited on $\mathrm{TiO}_{2}$, J. Catal., 159, 189-203.

Ploense L., Salazar M., Gurau B. and Smotkin E. (2000) Spectroscopic study of NEMCA promoted alkene isomerizations at PEM fuel cell Pd-Nafion cathodes, Solid State Ionics, 136-137, 713720.

Ploense L., Salazar M., Gurau B. and Smotkin E.S. (1997) Proton Spillover Promoted Isomerization of $n$-Butylenes on Pd-Black Cathodes/Nafion 117, JACS, 119, 11550-11551.

Politova T.I., Gal'vita G.G., Belyaev V.D. and Sobyanin V.A. (1997) Non-Faradaic catalysis: the case of CO oxidation over Ag-Pd alloy electrode in a solid oxide electrolyte cell, Catal. Lett., 44, 75-81.

Politova T.I., Sobyanin V.A. and Belyaev V.D. (1990) Ethylene hydrogenation in electrochemical cell with solid proton-conducting electrolyte, Reaction Kinetics and Catalysis Letters, 41,321-326.

Poppe J., Voelkening S., Schaak A., Schuetz E., Janek J., and Imbihl R. (1999) Electrochemical promotion of catalytic CO oxidation on $\mathrm{Pt} / \mathrm{YSZ}$ catalysts under low pressure conditions, Phys. Chem. Chem. Phys., 1, 5241-5249.

Pritchard J. (1990) Electrochemical Promotion, Nature, 343, 592-593.

Stoukides M. (1988) Applications of solid electrolytes in heterogeneous catalysis, Industrial \& Engineering Chemistry Research, 27, 1745-1750.

Stoukides M. and Vayenas C.G. (1981) The effect of Electrochemical Oxygen Pumping on the

Rate and Selectivity of Ethylene Oxidation on Polycrystalline Silver, J. Catal., 70,137-146.

Tsiakaras P. and Vayenas C.G. (1993), Non-Faradaic Electrochemical Modification of Catalytic Activity : VII. The Case of Methane Oxidation on Platinum, J. Catal., 140, 53-70.

Tsiplakides D., Neophytides S., Enea O., Jaksic M.M. and Vayenas C.G. (1997) Nonfaradaic Electrochemical Modification of the Catalytic Activity of Pt-Black Electrodes Deposited on Nafion 117 Solid Polymer Electrolytes, J. Electrochem. Soc., 144, 2072-2078. 
Vayenas C.G. and Neophytides S. (1996) Electrochemical Activation of Catalysis: In situ controlled promotion of catalyst surfaces, in Catalysis-Special periodical Report, Vol. 12, Royal Society of Chemistry, Cambridge, p. 199.

Vayenas C.G., Bebelis S. and Ladas S. (1990) The Dependence of Catalytic Activity on Catalyst Work Function, Nature, 343, 625-627.

Vayenas C.G., Bebelis S., Pliangos C., Brosda S. and Tsiplakides D. (2001), Electrochemical Activation of Catalysis: Promotion, Electrochemical Promotion and Metal-Support Interactions, Kluwer Academic/Plenum Publishers, New York.

Vayenas C.G., Jaksic M.M., Bebelis S. and Neophytides S.G. (1996) The Electrochemical Activation of Catalysis, in Modern Aspects of Electrochemistry, Vol. 29 (Bockris J.O.M., Conway B.E. and White R.E., eds.), Kluwer Academic/Plenum Publishers, New York, p. 57.

Vayenas C.G., Katsaounis A., Brosda S. and Hammad A. (2007) Electrochemical Modification of Catalytic Activity, in Handbook of Heterogeneous Catalysis by Ertl G., Knoetzinger H., Schuth F. and Weitcamp J. (Eds.), Weiheim.

Vayenas C.G., Yentekakis I.V., Bebelis S.I. and Neophytides S.G. (1995) Promotion of Catalyst Surfaces via Solid Electrolytes: The NEMCA effect, Ber. Buns. Phys. Chem., 99, 1393-1401.

Vernoux P., Gaillard F., Bultel L., Siebert E. and Primet M. (2001) Electrochemical Promotion of Propane and Propene Oxidation on Pt/YSZ, J. Catal., 208, 412-421.

Wieckowski A., Savinova E. and Vayenas C.G. (Eds.) (2003) Catalysis and Electrocatalysis at Nanoparticles, Marcel Dekker, Inc, New York.

Yentekakis I.V. and Vayenas C.G. (1988) The Effect of Electrochemical O2- Pumping on the Steady State and Oscillatory Behavior of $\mathrm{CO}$ oxidation on Polycrystalline Pt, J. Catal., 111, 170-188.

Yentekakis I.V., Lambert R.M., Tikhov M.S., Konsolakis M. and Kiousis V. (1998) Promotion by Sodium in Emission Control Catalysis: A Kinetic and Spectroscopic Study of the Pd-Catalyzed Reduction of NO by Propene, J. Catal., 176, 82-92. 